\title{
Organochlorine Burdens in Harbour Seals from the German Wadden Sea Collected During Two Phocine Distemper Epizootics and Ringed Seals from West Greenland Waters
}

\author{
Siebert $\mathrm{U}^{1 *}$, Heidmann $\mathrm{A}^{2}$, Friedhoff $\mathrm{N}^{2}$, Kruse $\mathrm{H}^{2}$, Rigét $\mathrm{F}^{3}$, Adler $\mathrm{S}^{1}$ and Maser $\mathrm{E}^{2}$
}

${ }^{1}$ Institute of Terrestrial and Aquatic Wildlife Research, University of Veterinary Medicine Hannover, Foundation, Werftstr. 6, 25761 Büsum, Germany

2Institute for Toxicology and Pharmakology, University of Kiel, Brunswiker Strasse 10, 24105 Kiel, Germany

${ }^{3}$ Department of Bioscience, Aarhus University, Frederiksborgvej 399, PO Box 358, DK-4000, Denmark

\begin{abstract}
Blubber and liver of harbour seals from the German Bight collected between 2001 and 2002 and ringed seals from West Greenland waters were investigated for hexachlorocyclohexane $(\alpha-, \beta-$ and $y-H C H)$, hexachlorobenzene $(\mathrm{HCB})$, dichlorodiphenyltrichlorethane and its metabolites (DDT, DDE and DDD), and polychlorinated biphenyls (PCBs). In blubber and liver of both species PCBs 138 and 153 showed the highest concentrations, followed by PCBs 187, 180 and 170. With the exception of PCB 52, the PCB burden in liver and blubber of harbour seals was higher than in ringed seals but not always statistically significant. Compared to levels found in harbour seals from the first seal epidemic in 1988, individuals collected in 2002 showed a decrease in concentrations of organochlorines. These data show that ringed seals from arctic waters are exposed to as large a variety of organochlorines as harbour seals from the North Sea.
\end{abstract}

Keywords: Organochlorines; Ringed seal; Harbor seal; Greenland; North Sea; German Wadden Sea

\section{Introduction}

Organochlorines such as hexachlorocyclohexane ( $\alpha-, \beta$ - and $\gamma-\mathrm{HCH})$, hexachlorobenzene (HCB), dichlorodiphenyltrichlorethane and its metabolites (DDT, DDE and DDD), and polychlorinated biphenyls (PCB) accumulate in the marine ecosystem as shown in several studies (reports of AMAP, UNEP, TMAP). Negative effects were demonstrated for most of those chemicals, resulting in a European ban of DDT in 1972 and of PCBs in 1989, and a worldwide ban in 2001 (www.chem.unep.ch/pops).

Marine mammals are at the top of the marine food chain and accumulate chemical pollutants in their tissues. Ringed seals (Phoca hispida) are widely distributed in arctic and subarctic waters [1,2]. They feed on fish and crustaceans (Parathemisto sp.) and give birth to their offspring on ice in the spring [3]. Harbour seals (Phoca vitulina) are the most common pinniped species in the Wadden Sea. They feed mainly on fish in the open North Sea and give birth on the sand banks of the Wadden Sea during the summer months [4]. Two epizootics caused by the phocine distemper virus (PDV) occurred among the harbour seal population of the Wadden Sea and adjacent waters [5-7]. These outbreaks resulted in the deaths of more than 23,000 harbour seals in 1988 and 30,000 in 2002 [8-10].

Negative effects of organochlorines have been described for different seal species. Stenosis/occlusion of the uterus, osteoporosis, colonic ulcera, splenic atrophy, and lymphocytic depletion in thymus and lymph nodes were found in grey and ringed seals from the Baltic Sea and harbour seals from the Wadden Sea [11-16]. Immunological investigations revealed that the impairment of the immune response by organochlorines increased the susceptibility to diseases caused by viruses such as phocine distemper virus $[17,18]$. Therefore, an effect on the occurrence of epizootics in the harbour seal populations of the North and Baltic Seas could not be ruled out [8].

The objective of this study was to compare findings from German harbour seals collected around the two PDV epizootics in 1988 and
2002 and to examine whether the banning of DDT and PCB has resulted in a decrease of the levels in seals. Concentrations of different organochlorines in seals from West Greenland waters, far from the industrialised areas in Europe and North America, were compared with those from the North Sea.

\section{Materials and Methods}

\section{Sample collection}

Harbour seals from the German waters were collected between June 2001 and October 2002 through the stranding network of SchleswigHolstein. Blubber and liver samples were taken during routine post mortem examination conducted during monitoring programmes [19]. Results of 26 harbour seals for the comparison of PDV-positive and PDV-negative animals (Table 1: animals 1-26) and 20 harbour seals were included for the comparison between ringed and harbour seals (Table 1: animals 10-29).

Blubber and liver samples of 20 ringed seals hunted by Inuits in Qeqertarsuaq, West Greenland were collected during April and May 2002. 14 ringed seals were males (all subadults) and 6 were females (2 adults and 4 subadults) (Table 1: animals 30-49).

All tissue samples were taken with stainless steel instruments, Greenlandic samples were placed in optically opaque glass jars and

${ }^{*}$ Corresponding author: Dr. Ursula Siebert, Institute of Terrestrial and Aquatic Wildlife Research, University of Veterinary Medicine Hannover, Foundation, Werftstr. 6, 25761 Büsum, Germany, Tel: 49-511-8568158; Fax: 49-511-8568181; E-mail: ursula.siebert@tiho-hannover.de

Received October 19, 2011; Accepted February 13, 2012; Published February 15, 2012

Citation: Siebert U, Heidmann A, Friedhoff N, Kruse H, Rigét F, et al. (2012) Organochlorine Burdens in Harbour Seals from the German Wadden Sea Collected During Two Phocine Distemper Epizootics and Ringed Seals from West Greenland Waters. J Environment Analytic Toxicol 2:126. doi:10.4172/2161-0525.1000126

Copyright: ( 2012 Siebert U, et al. This is an open-access article distributed under the terms of the Creative Commons Attribution License, which permits unrestricted use, distribution, and reproduction in any medium, provided the original author and source are credited. 
Citation: Siebert U, Heidmann A, Friedhoff N, Kruse H, Rigét F, et al. (2012) Organochlorine Burdens in Harbour Seals from the German Wadden Sea Collected During Two Phocine Distemper Epizootics and Ringed Seals from West Greenland Waters. J Environment Analytic Toxicol 2:126. doi:10.4172/2161-0525.1000126

Page 2 of 8

\begin{tabular}{|c|c|c|c|c|}
\hline Seal number & Date of collection & Location of collection & Sex $(m=$ male,$f=$ female $)$ & Age Years \\
\hline \multicolumn{5}{|c|}{ North Sea Harbour seals (Phoca vitulina) } \\
\hline 1 & 13.09.2002 & Eiderstedt & $\mathrm{f}$ & 1.25 \\
\hline 2 & 05.05 .2002 & Helgoland & $\mathrm{f}$ & 1.0 \\
\hline 3 & 06.09.2002 & Eiderstedt & $\mathrm{m}$ & 0.25 \\
\hline 4 & 15.09.2002 & Eiderstedt & $\mathrm{m}$ & 0.25 \\
\hline 5 & 18.09.2002 & Eiderstedt & f & 1.25 \\
\hline 6 & 18.09.2002 & Eiderstedt & $\mathrm{f}$ & 1.25 \\
\hline 7 & 19.09.2002 & Eider-Wesselburen-Vollerwiek & f & 2.25 \\
\hline 8 & 02.10 .2002 & Sylt & $\mathrm{m}$ & 5 \\
\hline 9 & 02.10 .2002 & Sylt & f & 0.25 \\
\hline 10 & 21.08.2002 & Eiderstedt & $\mathrm{m}$ & 7 \\
\hline 11 & 31.05.2002 & Helgoland & f & 2 \\
\hline 12 & 25.07 .2002 & Sylt & $\mathrm{m}$ & 6 \\
\hline 13 & 29.08.2002 & Eiderstedt & f & 1.25 \\
\hline 14 & 02.09.2002 & Eiderstedt & $\mathrm{m}$ & 1.25 \\
\hline 15 & 29.08 .2002 & Ostsee & $\mathrm{m}$ & 2.25 \\
\hline 16 & 04.06 .2002 & Eiderstedt & f & 0.1 \\
\hline 17 & 11.07.2002 & Amrum-Fohr-Dagebüll & $\mathrm{m}$ & 0.1 \\
\hline 18 & 12.08 .2002 & Amrum-Fohr-Dagebüll & $\mathrm{m}$ & 1.25 \\
\hline 19 & 19.07.2002 & Helgoland & $\mathrm{m}$ & 1 \\
\hline 20 & 15.08.2002 & Helgoland & $\mathrm{m}$ & 4 \\
\hline 21 & 03.09.2002 & Eiderstedt & $\mathrm{m}$ & 13 \\
\hline 22 & 02.09 .2002 & Amrum-Fohr-Dagebüll & f & 0.25 \\
\hline 23 & 03.09.2002 & Eiderstedt & $\mathrm{f}$ & 1.25 \\
\hline 24 & 05.09 .2002 & Eiderstedt & $\mathrm{m}$ & 6 \\
\hline 25 & 05.09 .2002 & Eiderstedt & f & 10 \\
\hline 26 & 05.09.2002 & Eiderstedt & $\mathrm{f}$ & 3 \\
\hline 27 & 05.06 .2001 & Amrum-Fohr-Dagebüll & f & $>1.5$ \\
\hline 28 & 11.06 .2001 & Sylt & f & 8 \\
\hline 29 & 06.09 .2002 & Eiderstedt & $f$ & 8 \\
\hline \multicolumn{5}{|c|}{ Greenland Ringed seals (Phoca hispida) } \\
\hline 30 & 24.04 .2002 & Qeqertarsuaq, Disko Fjord & $\mathrm{m}$ & 0.5 \\
\hline 31 & 24.04.2002 & Qeqertarsuaq, Disko Fjord & $\mathrm{m}$ & 0.5 \\
\hline 32 & 24.04 .2002 & Qeqertarsuaq, Disko Fjord & $\mathrm{m}$ & 0.5 \\
\hline 33 & 24.04 .2002 & Qeqertarsuaq, Disko Fjord & $\mathrm{m}$ & 0.5 \\
\hline 34 & 24.04.2002 & Qeqertarsuaq, Disko Fjord & $\mathrm{m}$ & 0.5 \\
\hline 35 & 24.04 .2002 & Qeqertarsuaq, Disko Fjord & $\mathrm{m}$ & 0.5 \\
\hline 36 & 28.04 .2002 & Qeqertarsuaq, Disko Fjord & $\mathrm{m}$ & 0.5 \\
\hline 37 & 28.04.2002 & Qeqertarsuaq, Disko Fjord & $\mathrm{m}$ & 0.5 \\
\hline 38 & 28.04.2002 & Qeqertarsuaq, Disko Fjord & $\mathrm{m}$ & 0.5 \\
\hline 39 & 01.05 .2002 & Qeqertarsuaq, Disko Fjord & $\mathrm{m}$ & 0.5 \\
\hline 40 & 24.04 .2002 & Qeqertarsuaq, Disko Fjord & $\mathrm{m}$ & 1.5 \\
\hline 41 & 24.04 .2002 & Qeqertarsuaq, Disko Fjord & $\mathrm{m}$ & 1.5 \\
\hline 42 & 01.05 .2002 & Qeqertarsuaq, Disko Fjord & $\mathrm{m}$ & 1.5 \\
\hline 43 & 28.04.2002 & Qeqertarsuaq, Disko Fjord & $\mathrm{m}$ & 3.5 \\
\hline 44 & 01.05 .2002 & Qeqertarsuaq, Disko Fjord & f & 0.5 \\
\hline 45 & 01.05 .2002 & Qeqertarsuaq, Disko Fjord & f & 0.5 \\
\hline 46 & 28.04.2002 & Qeqertarsuaq, Disko Fjord & f & 1,5 \\
\hline 47 & 24.04 .2002 & Qeqertarsuaq, Disko Fjord & f & 2.5 \\
\hline 48 & 24.04 .2002 & Qeqertarsuaq, Disko Fjord & f & 3.5 \\
\hline 49 & 24.04 .2002 & Qeqertarsuaq, Disko Fjord & f & 4.5 \\
\hline
\end{tabular}

Table 1: Date and location where ringed and harbour seals were collected, sex and age.

German samples were placed in aluminum foil and stored in a $-18^{\circ} \mathrm{C}$ freezer until analysis. Because of limited sample size varying numbers of samples were available for individual PCB investigations.

\section{Analysis of organochlorines}

Standards for PCB congeners (IUPAC-no) 28, 52, 101, 118, 128, $138,153,170,177,180,183,187,197, \beta-\mathrm{HCH}, \gamma-\mathrm{HCH}$ and $4,4-\mathrm{DDT}$ solved in isooctane produced by Dr Ehrenstorfer, Augsburg, Germany, and for $\alpha-\mathrm{HCH}, \mathrm{HCB}, 4,4^{\prime}-\mathrm{DDE}$ and $4,4^{\prime}$-DDD produced by Riedel De Haen, Seelze, Germany, were used. PCB congener 112 from Dr Ehrenstorfer, Augsburg, Germany, was added as an internal standard. Acetone, $\mathrm{n}$-hexane, isooctane and dichloromethane (SupraSolv) were purchased from Merck, Darmstadt, Germany. 
Citation: Siebert U, Heidmann A, Friedhoff N, Kruse H, Rigét F, et al. (2012) Organochlorine Burdens in Harbour Seals from the German Wadden Sea Collected During Two Phocine Distemper Epizootics and Ringed Seals from West Greenland Waters. J Environment Analytic Toxicol 2:126. doi:10.4172/2161-0525.1000126

Page 3 of 8

Organochlorines were analysed as described by [20]. The samples were extracted by a microwave MSP 1000 (SP-19, CEM Corporation, Matthews, NC,USA). 0.5-1 g tissue sample into $100 \mathrm{ml}$ microwave vessel, $10 \mathrm{ml}$ acetone (SupraSolv, Merck, Darmstadt, Deutschland) and $10 \mathrm{ml}$ internal standard. After 45 min samples were cooled to $24^{\circ} \mathrm{C}$. Organochlorine compounds were separated with GC-ECD (Varian). The organochlorine concentrations were calculated on a lipid-weight basis (Varian Star Chromatography Workstation 5.31).

For statistical analysis of the data the statistical open source platform R version 2.9.2 (R Development Core Team 2009) was used.

Testing for significant differences between the pollution levels in liver and blubber of the harbour seals, distinguished for PDV-positive and PDV-negative, a T-test was applied for simplicity as the values were more or less symmetrically distributed around the mean. As the number of animals with both liver and blubber data available was low, the results must be viewed with caution.

For comparison of the harbour seals data of from seal die-off in 1988 [21] and in 2002, only the mean values of the pollutant levels for the 1988 data were available. Here, a one-sample T-test was used.

The effect of age on the pollutant levels was tested using a regression analysis between the single pollution level as response and age as predictor, applying a GLM using Poisson error distribution with a correction of the standard errors using a quasi-GLM with a second order polynomial for males and females separately in combination with a backward selection. The $5 \%$ level of statistical significance was selected.
When comparing the pollution levels between ringed and harbour seals and within each population between liver and blubber, a general linear model (GLM) was applied using Poisson error distribution with a correction of the standard errors using a quasi-GLM [22,23], as the variance is different between both populations and, as mentioned earlier, the sample size is low. With a larger sample size with comparable variance structure, a GLM with log normal distribution would have been used.

\section{Results and Discussion}

\section{Comparison between harbour seals found around the two seal epizootics}

Harbour seals were collected in and around the year 2002 when the second phocine distemper virus epizootic occurred [6,7]. 15 individuals were infected with phocine distemper virus as shown by PCR and immunocytochemistry [7]. Contrary to males, infected females showed higher concentrations of organochlorines in the liver than those who tested negative (Table 2, Figure 1). In liver tissue, the results were significant for DDE using a T-test $(\mathrm{t}=2.93, \mathrm{p}$-value $=$ $0.01, \mathrm{df}=10.99$ ) and most of the PCBs (e.g. PCB 128: $\mathrm{t}=2.49$, $\mathrm{p}$-value $=0.03, \mathrm{df}=10.081)$ congeners. In blubber tissue, however, results did not show significant differences. The correlation between PCBs concentrations and susceptibility to phocine distemper virus infections had been investigated through different research activities during the epizootics. [24] found higher organochlorine (OC) concentrations in the blubber of diseased harbour seals compared to those who survived the die-off. A feeding experiment showed that the immunosuppressive

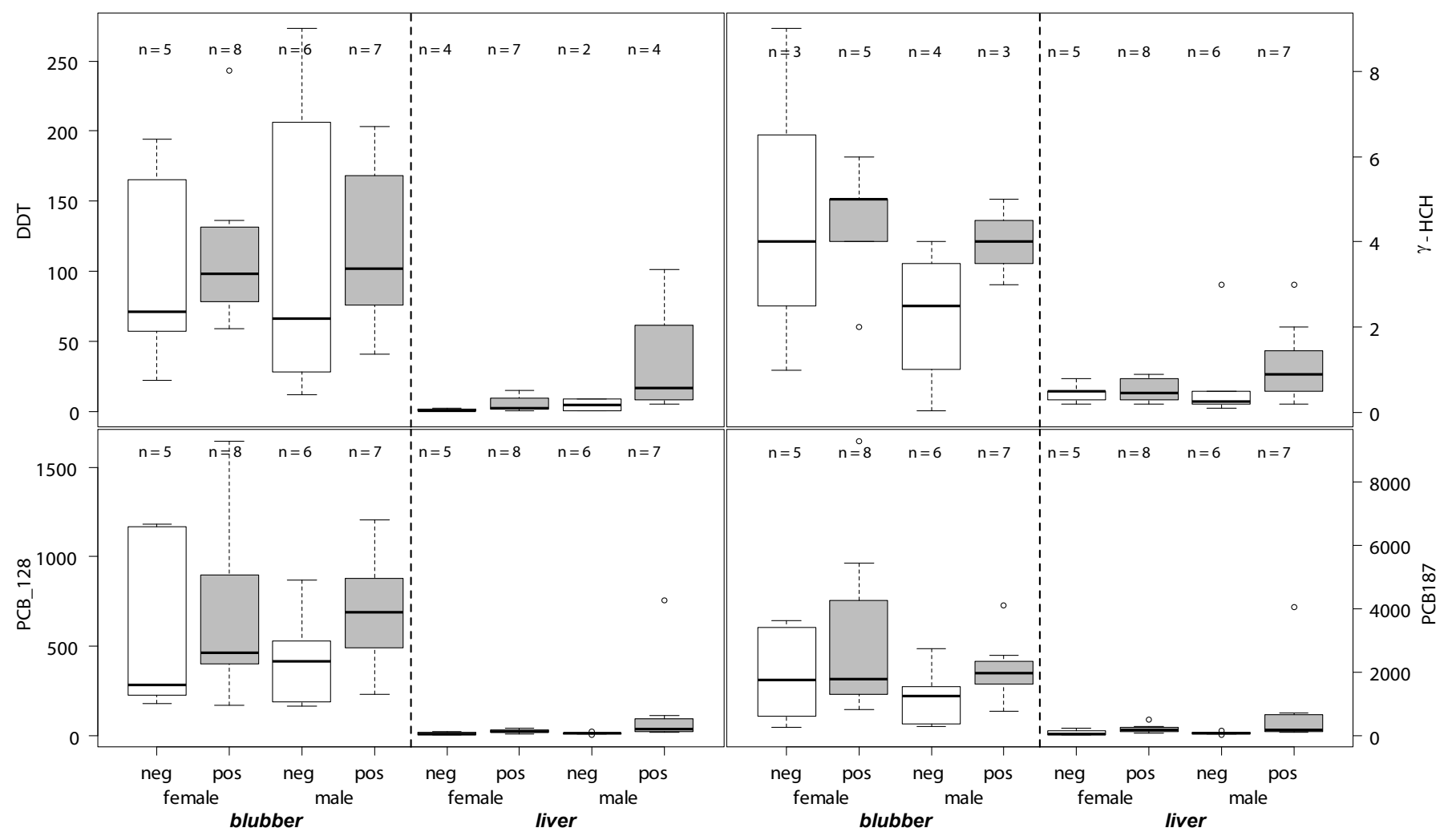

Figure 1: Comparison of harbour seals with (pos) and without (neg) PDV infection subdivided by organ and sex (ng/g lipid weight). $\mathrm{N}=\mathrm{number}$, DDT = dichlorodiphenyltrichlorethane, $\mathrm{HCH}=$ hexachlorocyclohexane, $\mathrm{PCB}=$ polychlorinated biphenyls. 
Citation: Siebert U, Heidmann A, Friedhoff N, Kruse H, Rigét F, et al. (2012) Organochlorine Burdens in Harbour Seals from the German Wadden Sea Collected During Two Phocine Distemper Epizootics and Ringed Seals from West Greenland Waters. J Environment Analytic Toxicol 2:126. doi:10.4172/2161-0525.1000126

Page 4 of 8

\begin{tabular}{|c|c|c|c|c|c|c|c|}
\hline \multirow[b]{2}{*}{ pollutant } & \multicolumn{4}{|c|}{ blubber } & \multicolumn{3}{|c|}{ liver } \\
\hline & sex & neg & pos & $\mathbf{p}$ & neg & pos & $p$ \\
\hline \multirow[t]{3}{*}{$\alpha-\mathrm{HCH}$} & all & $5.64(5.51 ; 11)$ & $6.27(2.78 ; 15)$ & n.s. & $0.13(0.05 ; 4)$ & $0.11(0.08 ; 3)$ & n.s. \\
\hline & female & $4.61(3.7 ; 5)$ & $7.13(2.95 ; 8)$ & n.s. & $0.2(-; 1)$ & $0.2(-; 1)$ & - \\
\hline & male & $6.51(6.91 ; 6)$ & $5.29(2.42 ; 7)$ & n.s. & $0.1(0 ; 3)$ & $0.07(0.04 ; 2)$ & n.s. \\
\hline \multirow[t]{3}{*}{$\beta-\mathrm{HCH}$} & all & $35(26.63 ; 3)$ & $17.64(7.88 ; 8)$ & n.s. & $0.43(0.49 ; 3)$ & $0.3(0.14 ; 2)$ & n.s. \\
\hline & female & $38(-; 1)$ & $19.25(4.57 ; 4)$ & - & $1(-; 1)$ & $0.2(-; 1)$ & - \\
\hline & male & $33.5(37.48 ; 2)$ & $16.02(10.82 ; 4)$ & n.s. & $0.15(0.07 ; 2)$ & $0.4(-; 1)$ & - \\
\hline \multirow[t]{3}{*}{$\mathrm{Y}-\mathrm{HCH}$} & all & $3.29(2.92 ; 7)$ & $4.25(1.28 ; 8)$ & n.s. & $0.6(0.82 ; 11)$ & $0.81(0.76 ; 15)$ & n.s. \\
\hline & female & $4.67(4.04 ; 3)$ & $4.4(1.52 ; 5)$ & n.s. & $0.46(0.23 ; 5)$ & $0.53(0.28 ; 8)$ & n.s. \\
\hline & male & $2.26(1.69 ; 4)$ & $4(1 ; 3)$ & n.s. & $0.72(1.13 ; 6)$ & $1.14(1.01 ; 7)$ & n.s. \\
\hline \multirow[t]{3}{*}{ НСВ } & all & $2.46(3.1 ; 7)$ & $1.99(2.68 ; 4)$ & n.s. & $9.16(12.03 ; 7)$ & $20.68(43.37 ; 14)$ & n.s. \\
\hline & female & $7(0 ; 2)$ & $2.43(3.09 ; 3)$ & n.s. & $6(4.55 ; 4)$ & $10.19(16.22 ; 8)$ & n.s. \\
\hline & male & $0.65(0 ; 5)$ & $0.65(-; 1)$ & - & $13.37(18.89 ; 3)$ & $34.67(64.13 ; 6)$ & n.s. \\
\hline \multirow[t]{3}{*}{ Ocs } & all & $0.04(0 ; 2)$ & $15(27.46 ; 9)$ & n.s. & - & $0.25(0.07 ; 2)$ & - \\
\hline & female & $0.04(0 ; 2)$ & $23.81(35.88 ; 5)$ & n.s. & - & - & - \\
\hline & male & - & $4(1.83 ; 4)$ & - & - & $0.25(0.07 ; 2)$ & - \\
\hline \multirow[t]{3}{*}{ DDD } & all & $26.09(23.1 ; 11)$ & $35.67(37.74 ; 15)$ & n.s. & $2.48(2.78 ; 11)$ & $6.73(12.95 ; 15)$ & n.s. \\
\hline & female & $34.2(33.69 ; 5)$ & $45.63(50.57 ; 8)$ & n.s. & $2.26(1.7 ; 5)$ & $3.25(2.25 ; 8)$ & n.s. \\
\hline & male & $19.33(6.25 ; 6)$ & $24.29(7.5 ; 7)$ & n.s. & $2.67(3.61 ; 6)$ & $10.71(18.72 ; 7)$ & n.s. \\
\hline \multirow[t]{3}{*}{ DDE } & all & $1254.45(974.21 ; 11)$ & $1683.53(1092.04 ; 15)$ & n.s. & $31.09(23.96 ; 11)$ & $153.07(308.33 ; 15)$ & n.s. \\
\hline & female & $1351(1291.77 ; 5)$ & $1820.38(1452.1 ; 8)$ & n.s. & $23.2(18.38 ; 5)$ & $64.13(31.92 ; 8)$ & s. \\
\hline & male & $1174(739.02 ; 6)$ & $1527.14(518.76 ; 7)$ & n.s. & $37.67(27.63 ; 6)$ & $254.71(445.02 ; 7)$ & n.s. \\
\hline \multirow[t]{3}{*}{ DDT } & all & $105.45(89.15 ; 11)$ & $116.73(57.81 ; 15)$ & n.s. & $2.05(3.48 ; 6)$ & $16.19(28.94 ; 11)$ & n.s. \\
\hline & female & $101.8(73.86 ; 5)$ & $114.63(58.26 ; 8)$ & n.s. & $0.78(0.87 ; 4)$ & $5.58(5.91 ; 7)$ & n.s. \\
\hline & male & $108.5(107.27 ; 6)$ & $119.14(61.85 ; 7)$ & n.s. & $4.6(6.22 ; 2)$ & $34.75(44.72 ; 4)$ & n.s. \\
\hline \multirow[t]{3}{*}{ PCB_101 } & all & 419.27 (368.28; 11) & $523.67(363.32 ; 15)$ & n.s. & $8.64(5.66 ; 11)$ & $36.13(56.62 ; 15)$ & n.s. \\
\hline & female & $593(498.81 ; 5)$ & $617.13(478.9 ; 8)$ & n.s. & $7.8(6.26 ; 5)$ & $20.5(9.43 ; 8)$ & s. \\
\hline & male & $274.5(129.95 ; 6)$ & $416.86(124.42 ; 7)$ & n.s. & $9.33(5.61 ; 6)$ & $54(81.72 ; 7)$ & n.s. \\
\hline \multirow[t]{3}{*}{ PCB_118 } & all & $110.91(76.81 ; 11)$ & $149.53(95.87 ; 15)$ & n.s. & $2.47(1.48 ; 10)$ & $7.33(8.52 ; 15)$ & s. \\
\hline & female & $144(102.53 ; 5)$ & $176.88(125.41 ; 8)$ & n.s. & $1.97(1.26 ; 5)$ & $4.63(2.26 ; 8)$ & s. \\
\hline & male & $83.33(37.16 ; 6)$ & $118.29(30.97 ; 7)$ & n.s. & $2.96(1.65 ; 5)$ & $10.43(11.93 ; 7)$ & n.s. \\
\hline \multirow[t]{3}{*}{ PCB_128 } & all & $511.09(387.32 ; 11)$ & $680.27(405.52 ; 15)$ & n.s. & $11.73(7.59 ; 11)$ & $83(188.5 ; 15)$ & n.s. \\
\hline & female & $607.6(519.37 ; 5)$ & 667.13 (484.22; 8) & n.s. & $11(8.97 ; 5)$ & $25(11.15 ; 8)$ & s. \\
\hline & male & $430.67(259.15 ; 6)$ & $695.29(331.17 ; 7)$ & n.s. & $12.33(7.06 ; 6)$ & $149.29(270.47 ; 7)$ & n.s. \\
\hline \multirow[t]{3}{*}{ PCB_138 } & all & $5228.73(4396.64 ; 11)$ & $7680.87(4914.99 ; 15)$ & n.s. & $148.45(107.17 ; 11)$ & $1066.47(2352.5 ; 15)$ & n.s. \\
\hline & female & $6250.6(5975.8 ; 5)$ & $8140.38(5998.88 ; 8)$ & n.s. & $143.4(136.11 ; 5)$ & $341.75(155.22 ; 8)$ & s. \\
\hline & male & $4377.17(2859.77 ; 6)$ & $7155.71(3712.02 ; 7)$ & n.s. & $152.67(90.01 ; 6)$ & $1894.71(3374.11 ; 7)$ & n.s. \\
\hline \multirow[t]{3}{*}{ PCB_153 } & all & $6509.73(5409.98 ; 11)$ & $9872(7003.68 ; 15)$ & n.s. & $163.73(110.91 ; 11)$ & $1340.47(2981.11 ; 15)$ & n.s. \\
\hline & female & $7747.2(7206.37 ; 5)$ & $10838.63(8989.95 ; 8)$ & n.s. & $147.2(128.34 ; 5)$ & $397.75(189.87 ; 8)$ & s. \\
\hline & male & $5478.5(3766.02 ; 6)$ & $8767.29(4182.69 ; 7)$ & n.s. & $177.5(104.53 ; 6)$ & $2417.86(4260.89 ; 7)$ & n.s. \\
\hline \multirow[t]{3}{*}{ PCB_170 } & all & $987.45(836.67 ; 11)$ & $1712.4(1637.46 ; 15)$ & n.s. & $27.45(21.2 ; 11)$ & $257.2(539.91 ; 15)$ & n.s. \\
\hline & female & $1289.4(1131.75 ; 5)$ & $2134.38(2132.86 ; 8)$ & n.s. & $29.4(28.14 ; 5)$ & $91.88(60.9 ; 8)$ & s \\
\hline & male & $735.83(456.29 ; 6)$ & $1230.14(663.52 ; 7)$ & n.s. & $25.83(16.08 ; 6)$ & $446.14(773.15 ; 7)$ & n.s. \\
\hline \multirow[t]{2}{*}{ PCB_177 } & all & $379.64(293.34 ; 11)$ & 648.07 (572.99; 15) & n.s. & $19.36(15.45 ; 11)$ & $112.13(225.08 ; 15)$ & n.s. \\
\hline & female & $489.6(387.22 ; 5)$ & $743.75(753.64 ; 8)$ & n.s. & $24.6(21.55 ; 5)$ & $51.5(39.55 ; 8)$ & n.s. \\
\hline
\end{tabular}


Citation: Siebert U, Heidmann A, Friedhoff N, Kruse H, Rigét F, et al. (2012) Organochlorine Burdens in Harbour Seals from the German Wadden Sea Collected During Two Phocine Distemper Epizootics and Ringed Seals from West Greenland Waters. J Environment Analytic Toxicol 2:126. doi:10.4172/2161-0525.1000126

Page 5 of 8

\begin{tabular}{|c|c|c|c|c|c|c|c|}
\hline & male & $288(173.14 ; 6)$ & $538.71(278.02 ; 7)$ & n.s. & $15(7.46 ; 6)$ & $181.43(325.39 ; 7)$ & n.s. \\
\hline \multirow[t]{3}{*}{ PCB_180 } & all & $1435.27(1165.68 ; 11)$ & $2519.67(2567.63 ; 15)$ & n.s. & $38.73(25.94 ; 11)$ & $361.8(722.86 ; 15)$ & n.s. \\
\hline & female & $1832.6(1551.83 ; 5)$ & $3212.25(3390.98 ; 8)$ & n.s. & $38(33.04 ; 5)$ & $141.5(101.12 ; 8)$ & s. \\
\hline & male & $1104.17(708.27 ; 6)$ & $1728.14(772.86 ; 7)$ & n.s. & $39.33(21.71 ; 6)$ & $613.57(1033.75 ; 7)$ & n.s. \\
\hline \multirow[t]{3}{*}{ PCB_183 } & all & $308.82(245.45 ; 11)$ & $584.6(525.04 ; 15)$ & n.s. & $8.87(5.83 ; 11)$ & $85.6(180.8 ; 15)$ & n.s. \\
\hline & female & $391.8(323.26 ; 5)$ & $675.38(660.03 ; 8)$ & n.s. & $8.4(7.44 ; 5)$ & $32.13(26.09 ; 8)$ & s. \\
\hline & male & $239.67(155.79 ; 6)$ & $480.86(333.83 ; 7)$ & n.s. & $9.27(4.82 ; 6)$ & $146.71(259.44 ; 7)$ & n.s. \\
\hline \multirow[t]{3}{*}{ PCB_187 } & all & $1552.73(1219.47 ; 11)$ & $2637.47(2219.62 ; 15)$ & n.s. & $83.45(72.03 ; 11)$ & $499.4(997.21 ; 15)$ & n.s. \\
\hline & female & $1928.4(1544.03 ; 5)$ & $3098.25(2900.05 ; 8)$ & n.s. & $96.4(96.74 ; 5)$ & $206.13(136.68 ; 8)$ & n.s. \\
\hline & male & $1239.67(899.04 ; 6)$ & $2110.86(1037.83 ; 7)$ & n.s. & $72.67(50.82 ; 6)$ & $834.57(1432.75 ; 7)$ & n.s. \\
\hline \multirow[t]{3}{*}{ PCB_194 } & all & $158.27(158.59 ; 11)$ & $291.67(396.52 ; 15)$ & n.s. & $3.71(2.47 ; 11)$ & $48.27(91.63 ; 15)$ & n.s. \\
\hline & female & $197.6(204.16 ; 5)$ & $357.88(522.43 ; 8)$ & n.s. & $3.72(3.21 ; 5)$ & $21.13(19.41 ; 8)$ & s. \\
\hline & male & $125.5(118.81 ; 6)$ & $216(189.52 ; 7)$ & n.s. & $3.7(1.99 ; 6)$ & $79.29(130.56 ; 7)$ & n.s. \\
\hline \multirow[t]{3}{*}{ PCB_28 } & all & $19.07(26.77 ; 2)$ & - & - & - & - & - \\
\hline & female & $0.14(-; 1)$ & - & - & - & - & - \\
\hline & male & $38(-; 1)$ & - & - & - & - & - \\
\hline \multirow[t]{3}{*}{ PCB_52 } & all & $116.45(106.41 ; 11)$ & $140.2(102.67 ; 15)$ & n.s. & $2.34(1.12 ; 8)$ & $6.5(6.98 ; 14)$ & n.s. \\
\hline & female & $157.6(143.79 ; 5)$ & $161.25(117.91 ; 8)$ & n.s. & $2.5(1.29 ; 4)$ & $4.29(2.5 ; 7)$ & n.s. \\
\hline & male & $82.17(54.8 ; 6)$ & $116.14(84.31 ; 7)$ & n.s. & $2.18(1.09 ; 4)$ & $8.71(9.38 ; 7)$ & n.s. \\
\hline
\end{tabular}

Table 2: Levels of pollutants in PDV-positive (pos) and PDV-negative (neg) harbour seals separated for blubber and liver (ng/g lipid weight). Levels of pollutants were tested by T-test (s. significant, n.s. not significant) in blubber and liver. Given is the mean and in brackets the standard deviation with the number of available samples for each pollutant group.

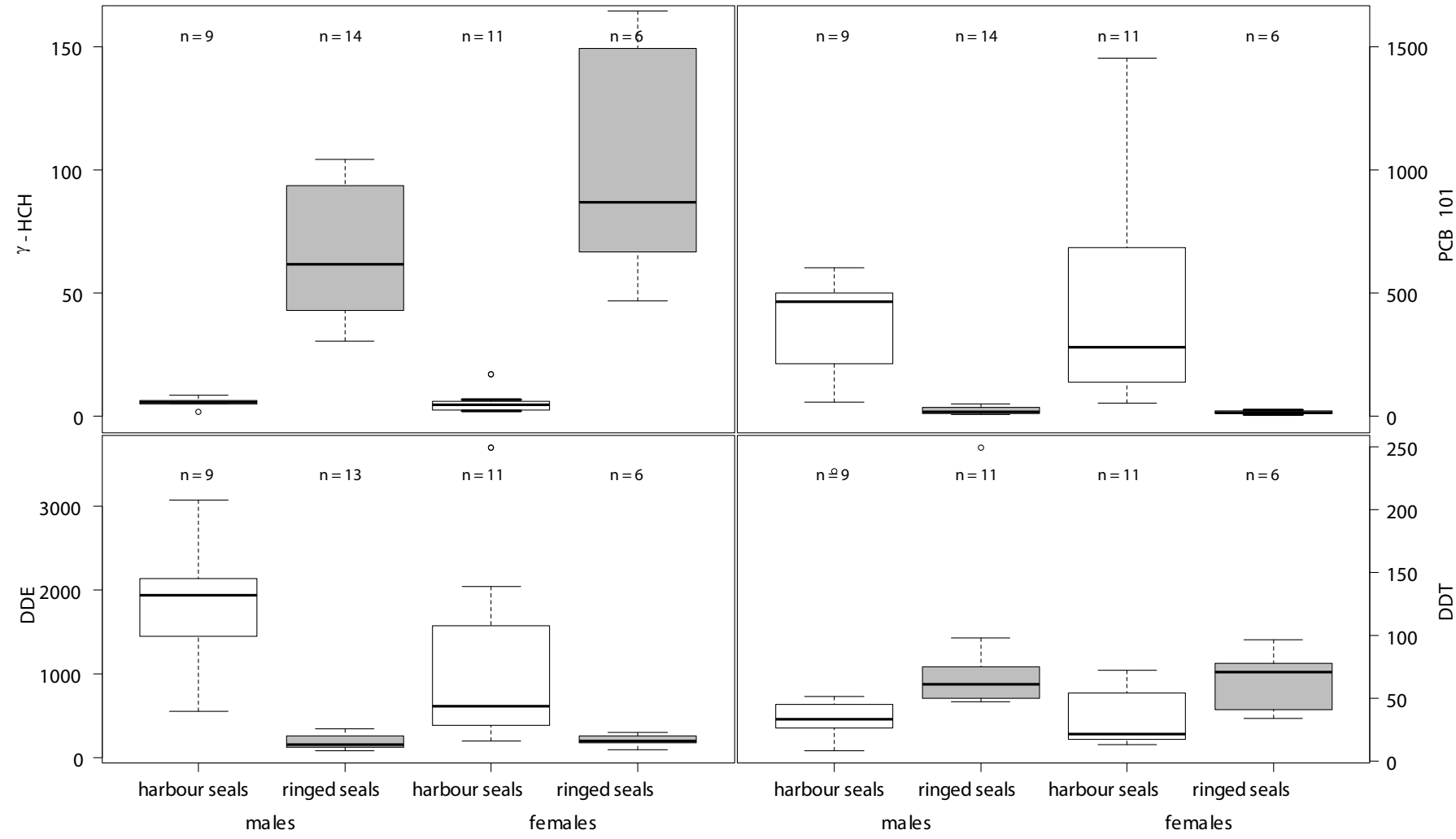

Figure 2: Level of pollutants in harbour and ringed seals separated by sex (ng/g lipid weight), $\mathrm{N}=$ number, $\mathrm{HCH}=$ hexachlorocyclohexane, $\mathrm{PCB}=$ polychlorinated biphenyls, DDT = dichlorodiphenyltrichlorethane, DDE = dichlorodiphenyldichlorethane. 
Citation: Siebert U, Heidmann A, Friedhoff N, Kruse H, Rigét F, et al. (2012) Organochlorine Burdens in Harbour Seals from the German Wadden Sea Collected During Two Phocine Distemper Epizootics and Ringed Seals from West Greenland Waters. J Environment Analytic Toxicol 2:126. doi:10.4172/2161-0525.1000126

Page 6 of 8

effect of PCBs increased the likelihood of mass mortalities due to viral infections [18].

\section{Comparison between regions}

All organochlorines analysed in the present study were found in seals from both areas (Table 4). In both species, hexachlorocyclohexane ( $\alpha-, \beta$ - and $\gamma-\mathrm{HCH})$, hexachlorobenzene (HCB), dichlorodiphenyltrichlorethane and its metabolites (DDT, $\mathrm{DDE}$ and DDD), and polychlorinated biphenyls (PCBs) were found. In blubber and liver of both species, PCBs 138 and 153 showed the highest concentrations, followed by PCBs 187, 180 and 170. The PCBs burden in blubber and liver of harbour seals was several times higher than in ringed seals (e.g., PCB 138) with the exception of PCB 52, which was highest in the liver of ringed seals. Levels of DDE and DDD were also higher in harbour seals (blubber - DDE: $\mathrm{t}=-7.94 \mathrm{p}<<0.01, \mathrm{df}=37$, DDD: $\mathrm{t}=-6.23 \mathrm{p}<<0.01, \mathrm{df}=33)$ than in ringed seals, only DDT was higher in blubber of ringed seals $(t=2.61 \mathrm{p}=0.01, \mathrm{df}=35)$. $\alpha-, \beta-\mathrm{HCH}$ and HCB in blubber were higher (e.g., $\alpha-\mathrm{HCH}: \mathrm{t}=11.73 \mathrm{p}<<0.01, \mathrm{df}=$ 38) but in liver lower in ringed seals than harbour seals (e.g., HCB: $t=$ $-5.32 \mathrm{p}<<0.01, \mathrm{df}=7$ ). For $\gamma-\mathrm{HCH}$ concentrations, it was the opposite, with higher levels in liver of ringed seals $(\mathrm{t}=2.81, \mathrm{p}=0.01, \mathrm{df}=13)$ and lower levels in blubber $(t=-5.34, p<<0.01, d f=26)$. The variance within the ringed and harbour seals concerning the single pollutants was high (Table 4, e.g. PCB 52 or DDT). This could not be explained by the parameters of age or sex available in this study.

Levels found in Greenlandic ringed seals from the west coast were similar to those in ringed seals from the same area of Greenland, Alaska and Canada [25-27]. But levels were lower than those in ringed seals originating from the east coast of Greenland, Norway and Svalbard $[26,28,29]$

\begin{tabular}{|l|l|l|l|l|l|l|}
\hline & \multicolumn{3}{|c|}{ blubber } & \multicolumn{3}{c|}{ liver } \\
\hline pollutant & mean & n & p & mean & n & p \\
\hline a-HCH & & & & & & \\
\hline 及-HCH & 141 & 149 & s. & 2 & 149 & s. \\
\hline Y-HCH & 90 & 149 & s. & 1 & 149 & s. \\
\hline HCB & 34 & 149 & s. & 2 & 149 & s. \\
\hline OCS & 27 & 149 & s. & 0,4 & 149 & s. \\
\hline DDD & 49 & 149 & s. & 1 & 149 & s. \\
\hline DDE & 202 & 149 & s. & 39 & 149 & s. \\
\hline DDT & 4847 & 149 & s. & 155 & 149 & n.s \\
\hline PCB_101 & 2829 & 149 & s. & 75 & 149 & s. \\
\hline PCB_118 & NA & 149 & s. & 23 & 149 & n.s \\
\hline PCB_128 & 1405 & - & - & - & - & - \\
\hline PCB_138 & 13929 & 149 & s. & 12 & 149 & n.s \\
\hline PCB_153 & 22971 & 149 & s. & 1226 & 149 & n.s \\
\hline PCB_170 & 2241 & 149 & s. & 101 & 149 & n.s \\
\hline PCB_177 & 1713 & 149 & s. & 58 & 149 & n.s \\
\hline PCB_180 & 6735 & 149 & s. & 83 & 149 & n.s \\
\hline PCB_183 & 1201 & 149 & s. & 12 & 149 & n.s \\
\hline PCB_187 & 2717 & 149 & n.s. & 46 & 149 & n.s \\
\hline PCB_194 & 394 & 149 & s. & 3 & 149 & n.s \\
\hline PCB_28 & - & - & - & - & - & - \\
\hline PCB_52 & 231 & 149 & s. & 4 & 149 & n.s \\
\hline PCb_3: & & & & & 149 & n.s \\
\hline
\end{tabular}

Table 3: Mean values of pollutants for harbour seals 1992 [Vagts] (ng/g lipid weight), standard deviation is not available. The means were tested for significan differences by one-sample T-test with the data of 2002, the result is given in the column p; s. = significant different, n.s. = not significant different.

\section{Temporal trends}

From 1988 to 1992, the burdens of PCBs and DDT in harbour seals from German waters increased [21,30]. But when comparing findings between 1988-1992 [21,30] and 2002 (this study), concentration levels of all pollutants decreased, e.g. $\alpha-\mathrm{HCH}$ and DDT by the factor 20 (Table 3 and $4, \mathrm{p}<<0.05$ ). Unfortunally no data on PCB levels of harbour seals from German waters are available for the period between 1992 and 2001 explaining when the decrease in body burden started. The decline in the burdens of $\mathrm{HCB}, \mathrm{HCH}$, OCS, DDT and DDD was distinct and confirmed earlier investigations [30]. A decreasing input can thus be assumed after the banning of technical $\mathrm{HCH}$ mixtures in many countries. The concentrations of PCBs and DDE decreased less noticeably because they are more persistent in the marine food web. Those findings were also confirmed in 18 harbour seals found dead in the Dutch Wadden Sea during the second PDV epizootic in 2002 [31] $\mathrm{HCH}$ and $\mathrm{HCB}$ levels showed a significant decline but PCBs, DDT and DDE did not decrease significantly.

In all investigations $\mathrm{PCBs} 138$ and 153 showed the highest concentrations. In general, 'legacy' persistent organic pollutants (POP) in arctic biota has showed decreasing trends during the past two to three decades [32]. This has also been the case for West Greenland ringed seals. For example, the concentrations of PCBs and DDT showed an annual decrease of 6.1 and $8.1 \%$, respectively, during the period 1994 to 2006 [27].

\section{Sex and age ratio}

Male and female ringed and harbour seals in this study did not show a significant difference in PCBs using a GLM for testing (e.g., PCB 101, ringed seals: $\mathrm{t}=-1.13, \mathrm{p}=0.28, \mathrm{df}=18$; harbour seals: $\mathrm{t}=$ $0.62 \mathrm{p}=0.54, \mathrm{df}=18$ ), DDT (ringed seals: $\mathrm{t}=-0.57, \mathrm{p}=0.58, \mathrm{df}=$ 18; harbour seals: $\mathrm{t}=-0.89, \mathrm{p}=0.39, \mathrm{df}=18)$ and $\alpha-, \beta$ - and $\gamma-\mathrm{HCH}$ concentrations (Figure 2). In contrast, findings from other studies indicate that adult males carry higher burdens of any of these chemicals than females [21,26,33,34]. According to Reijnders [35], a plateau in concentrations is reached at about 4 years because intake and excretion are balanced. Mature female marine mammals lose organochlorines during gestation and lactation [36,38], resulting in a reduction of the organochlorine burden. In contrast, males continue to accumulate organochlorines throughout life [37]. In the present study, most of the seals were young; especially the ringed seals from West Greenland and, therefore, no difference between the sexes could be expected.

Age correlation was insignificant (not shown), most likely due to the short age gradient of the investigated seals and the low representation of seals of higher age (Table 1). Young harbour seals already showed higher organochlorine concentrations when compared to ringed seals, most likely due to a transfer of the burden from contaminated female harbour seals during lactation [38]. In harbour seals from the Dutch Wadden Sea, newborns showed an even higher PCB burden than subadults [33,35]. Birnbaum [39] and Debier et al. [37] showed for harbour and grey seals that higher chlorinated PCB congeners are transferred in higher concentrations through the milk than lower chlorinated ones.

In summary the present study showed that female harbour seals infected with phocine distemper virus carried higher concentrations of organochlorine confirming previous investigations from other areas [24]. All organochlorines analysed in this investigation were found in seals from German and Greenlandic waters. HCH and HCB levels showed a significant decline but PCBs, DDT and DDE did not 
Citation: Siebert U, Heidmann A, Friedhoff N, Kruse H, Rigét F, et al. (2012) Organochlorine Burdens in Harbour Seals from the German Wadden Sea Collected During Two Phocine Distemper Epizootics and Ringed Seals from West Greenland Waters. J Environment Analytic Toxicol 2:126. doi:10.4172/2161-0525.1000126

Page 7 of 8

\begin{tabular}{|c|c|c|c|c|c|c|c|c|}
\hline & & ringed seals & & & harbour seals & & & \\
\hline & & & & & & & blubber & liver \\
\hline & blubber & liver & sig diff & blubber & liver & sig diff & rs:hs & rs:hs \\
\hline$\alpha-\mathrm{HCH}$ & $75.38(35.68 ; 20)$ & $11.81(5.65 ; 6)$ & s. & $6.13( \pm 4.22 ; 20)$ & $15.34( \pm 6.17 ; 2)$ & s. & s. & n.s \\
\hline$\beta-\mathrm{HCH}$ & $38.08(23.34 ; 20)$ & NA & - & $19.08( \pm 16.99 ; 13)$ & $159.66( \pm 13.64 ; 2)$ & n.s. & s. & - \\
\hline DDD & $2.16(1.04 ; 17)$ & $46.35( \pm N A ; 1)$ & - & $16.73( \pm 15.7 ; 18)$ & $174.17( \pm N A ; 1)$ & - & s. & - \\
\hline DDE & $190.15(76.16 ; 19)$ & $131.72(84.55 ; 13)$ & s. & $1487.3( \pm 1103.31 ; 20)$ & $1282.25( \pm 831.94 ; 8)$ & n.s. & s. & s. \\
\hline DDT & $74.17(48.62 ; 17)$ & $856.4(1969.39 ; 14)$ & n.s. & $43.51( \pm 48.07 ; 20)$ & $1113.23( \pm 910.22 ; 7)$ & s. & s. & n.s. \\
\hline $\mathrm{V}-\mathrm{HCH}$ & $4.94(2.63 ; 20)$ & $522.53(491.33 ; 10)$ & s. & $13.42( \pm 10.59 ; 8)$ & $59.64( \pm 29.62 ; 5)$ & s. & s. & s. \\
\hline HCB & $44.8(137.95 ; 20)$ & $33.77(8.42 ; 6)$ & s. & $18.32( \pm 59.1 ; 15)$ & $216.39( \pm 155.15 ; 3)$ & n.s. & n.s. & s. \\
\hline IS_OCS & $26.98(17.21 ; 19)$ & NA & - & $2.87( \pm 1.43 ; 6)$ & NA & - & s. & - \\
\hline PCB_101 & $22.27(12.53 ; 20)$ & NA & - & $450.69( \pm 417.33 ; 20)$ & $363.26( \pm 104.44 ; 5)$ & n.s. & s. & - \\
\hline PCB_112 & NA & $1879.65(1625.52 ; 13)$ & - & $83.97( \pm 14.48 ; 19)$ & $2668.31( \pm 1191.31 ; 7)$ & s. & - & n.s. \\
\hline PCB_118 & $23.33(18.13 ; 20)$ & $48.49(2.86 ; 2)$ & n.s. & $41.11( \pm 36.7 ; 20)$ & NA & - & s. & \\
\hline PCB_128 & NA & NA & - & $2945.87( \pm 10817.42 ; 20)$ & $741.7( \pm 701.79 ; 4)$ & n.s. & - & - \\
\hline PCB_138 & $51.71(19.86 ; 20)$ & $63.86(42.11 ; 7)$ & n.s. & $4276.75( \pm 3221.9 ; 20)$ & $8484.97( \pm 11510.3 ; 8)$ & s. & s. & n.s \\
\hline PCB_153 & $89.41(39.27 ; 20)$ & $332.18(619.82 ; 8)$ & n.s. & $5767.3( \pm 5029.21 ; 20)$ & $10681.63( \pm 15667.64 ; 8)$ & n.s. & s. & s. \\
\hline PCB_170 & $5.98(4.93 ; 20)$ & $21.76( \pm N A ; 1)$ & - & $1129.09( \pm 1329.68 ; 19)$ & $1883.62( \pm 2716.97 ; 7)$ & n.s. & s. & n.s. \\
\hline PCB_177 & $2.21( \pm N A ; 1)$ & NA & - & $444.99( \pm 339.27 ; 20)$ & $830.92( \pm 811.28 ; 8)$ & s. & n.s. & - \\
\hline PCB_180 & $21.91(13.1 ; 18)$ & $76.69(31.73 ; 2)$ & s. & $1642.61( \pm 1638.78 ; 19)$ & $2381.71( \pm 3702.93 ; 8)$ & n.s. & s. & n.s \\
\hline PCB_183 & NA & NA & - & $485.32( \pm 447.49 ; 14)$ & $876.76( \pm 1079.77 ; 4)$ & n.s. & - & - \\
\hline PCB_187 & $13.11(9.91 ; 16)$ & NA & - & $1787.66( \pm 1751.31 ; 20)$ & $4087( \pm 5684.59 ; 8)$ & s. & s. & - \\
\hline PCB_194 & $1.7(0.95 ; 2)$ & $69.52(49.83 ; 3)$ & n.s. & $180.79( \pm 237.47 ; 19)$ & $463.74( \pm 648.89 ; 7)$ & s. & n.s. & n.s. \\
\hline PCB_28 & $9.57(5.29 ; 16)$ & NA & - & $11.03( \pm 3.68 ; 11)$ & NA & - & n.s. & - \\
\hline PCB_52 & $11.95(5.36 ; 20)$ & $460.46(681.25 ; 14)$ & s. & $146.02( \pm 118.08 ; 20)$ & $224.35( \pm 149.6 ; 2)$ & n.s. & $\mathrm{s}$ & n.s \\
\hline
\end{tabular}

Table 4: Comparison of pollution levels between ringed and harbour seals in liver and blubber (ng/g lipid weight). Given is the mean and in brackets the standard deviation with the number of available samples for each pollutant group. sig diff: comparison between pollution levels within the ringed seals and harbour seals using a paired T-test. When comparing the pollution levels between ringed seals and harbour seals (rs:hs) for liver and blubber (last two columns) a GLM was used.

decrease significantly. Despite decreasing concentrations, PCBs and DDE burdens are still high (Table 4). Pathological findings such as loss of bone structure, leiomyoma and occlusion of the uterus associated with high organochlorine burdens for ringed and grey seals from the Baltic $[11,12,14]$ were not found in harbour seals from the North Sea $[7,19]$. However, concentrations of those substances are still at levels known to affect the immune and endocrine systems and to cause vitamin A deficiency in harbour seals and porpoises from the North Sea $[17,18,40-42]$. Therefore, a contribution of organochlorines to the severity of mass mortalities and effects in seals with high burdens cannot be ruled out. Additionally, harbour seals from the Wadden Sea are also exposed to other pollutants such as perfluorooctane sulfonate (PFOS), polybrominated diphenyl ethers (PBDEs) and heavy metals [31,43-45] as well as other effects of anthropogenic activities [4] so that continuous pressure on the health of the animals needs to be assumed and further investigations should be carried out.

\section{Acknowledgements}

We acknowledge the German Federal Agency of Environment Foundation for sponsoring the project. Harbour seals were collected in the course of investigations funded by the Ministry of Agriculture, Environment and Rural Development of Schleswig-Holstein and the Department "National Park and Marine Conservation" of the Schleswig-Holstein Agency for Coastal Defence, National Park and Marine Conservation. We thank people collecting animals and helping with sampling material. The sampling of ringed seals from Greenland was funded by the Danish Environmental Protection Agency as part of the environmental support programme Dancea. We are grateful to the hunters who secured the seal samples.

\section{References}

1. King JE (1983) Seals of the world. British Museum (Natural History) and Oxford University Press.

2. Wandrey R (1997) Wale und Robben der Welt. Franckh-Kosmos Verlags $\mathrm{GmbH} \& \mathrm{Co}$.
3. Siegstad H, Neve PB, Heide-Jørgensen MP, Härkönen T (1998) Diet of the ringed seal (Phoca hispida). Scientific Contribution NAMMCO 1: 229-241.

4. Reijnders RJH, Abt KF, Brasseur SMJM, Camphuysen KCJ, Reineking B, et al. (2005) Marine Mammals. In: Essink K, Dettmann C, Farke H, Laursen K Lürßen G, et al. (Eds): Wadden Sea Quality Status Report 2004. Wadden Sea Ecosystem No. 19. Trilateral Monitoring and Assessment Group, Common Wadden Sea Secretariat, Wilhelmshaven, Germany 305-318.

5. Kennedy S (1990) A review of the 1988 European seal epizootic. Veterinary Record 127: 563-567.

6. Jensen T, van de Bildt M, Dietz HH, Andersen TH, Hammer AS, et al. (2002) Another phocine distemper outbreak in Europe. Science 297: 209.

7. Müller G, Wohlsein P, Beineke A, Haas L, Greiser-Wilke I, et al. (2004) Phocine distemper in German seals in 2002. Emerging Infectious Diseases 10: 723-725.

8. Härkönen T, Dietz R, Reijnders PJH, Teilmann J, Thompson P, et al. (2006) Review of the seal epizootics in Europe. Diseases of Aquatic Organism 68 115-130.

9. Seibel H, Baumgärtner W, Müller G, Wohlsein P, Siebert U (2007) Retrospektive Analyse der zwei Seehundstaupe-Epidemien in der Nord- und Ostsee 1988 und 2002. Deutsche Tierärztliche Wochenschrift 114: 284-293.

10. Siebert U, Gulland F, Harder T, Jauniaux T, Seibel H, et al. (2011) Epizootics in harbour seals: Clinical aspects and epidemiology. NAMMCO 8: 265-274.

11. Helle E, Olsson M, Jensen S (1976) PCB levels correlated with pathological changes in seal uteri. Ambio 5: 261-263

12. Bergman A, Olsson M (1985) Pathology of Baltic grey seal and ringed sea females with special reference to adrenocortical hyperplasia: Is environmental pollution the cause of a widely distributed disease syndrome? Finnish Game Research 44: 47-62.

13. Reijnders PJH (1986) Reproductive failure in common seals feeding on fish from polluted coastal waters. Nature 324: 456-457.

14. Bergman A, Olsson M, Reiland S (1992) Skull-bone lesions in the Baltic grey seal (Halichoerus grypus). Ambio 21: 517-519.

15. Schumacher U, Zahler S, Horney HP, Heidemann G, Skrinisson K, et al. (1993) 
Citation: Siebert U, Heidmann A, Friedhoff N, Kruse H, Rigét F, et al. (2012) Organochlorine Burdens in Harbour Seals from the German Wadden Sea Collected During Two Phocine Distemper Epizootics and Ringed Seals from West Greenland Waters. J Environment Analytic Toxicol 2:126. doi:10.4172/2161-0525.1000126

Page 8 of 8

Histological investigation on the thyroid glands of marine mammals (Phoca vitulina, Phocoena phocoena) and the possible implication of marine pollution. J Wild Dis 29: 103-108

16. Bäcklin B, Eriksson ML, Olovsson M (2003) Histology of uterine leiomyoma and occurrence in relation to reproductive activity in the Baltic Gray Seal (Halichoerus grypus). Vet Pathol 40: 175-180.

17. De Swart RL, Ross PS, Vos JG, Osterhaus ADME (1996) Impaired immunity in harbour seals (Phoca vitulina) exposed to bioaccumulated environmental contaminants: review of a long-term feeding study. Environmental Health Perspective 104: 823-828.

18. Ross PS, de Swart RL, Addison R, van Loveren H, Vos JG, et al. (1996) Contaminant-induced immunotoxicity in harbour seals: wildlife at risk? Toxicology 112: 157-169.

19. Siebert U, Wohlsein P, Lehnert K, Baumgärtner W (2007) Pathological findings in Harbour Seals (Phoca vitulina): 1996-2005. J Comp Pathol 137: 47-58.

20. Willitzkat FR (1999) Anreicherung von persistenten chlororganischen Verbindungen und Nitromoschusverbindungen in der aquatischen Nahrungskette. Inaugural-dissertation. Freie Universität Berlin, Berlin, Deutschland 125

21. Vagts A (1992) Nachweis ausgwählter Organochlorverbindungen in Organen des Seehundes (Phoca vitulina) - Ein Beitrag zur Aufklärung der Ursachen des Seehundsterbens 1988. Dissertation, Agrarwissenschaftliche Fakultät der Christian-Albrechts-Universität zu Kiel.

22. McCullagh P, Nelder JA (1989) Generlized Linear Models. $2^{\text {nd }}$ ed, Chapmann \& Hall/CRC, Boca Raton, Florida.

23. Zuur AF, leno IE, Elphick CS (2009) A protocol for data exploration to avoid common statistical problems. Methods in Ecology and Evolution 1: 3-14.

24. Hall AJ, Law RJ, Wells DE, Harwood J, Ross HM, et al. (1992) Organochlorine levels in common seals (Phoca vitulina) which were victims and survivors of the 1988 phocine distemper epizootic. Science of the Total Environment 115: $145-162$.

25. Krahn MM, Becker PR, Tilbury KL, Stein JE (1997) Organochlorine contaminants in blubber of four seal species: Integrating biomonitoring and specimen banking. Chemosphere 34: 2109-2121.

26. Cleemann M, Rigét F, Paulsen GB, de Boer J, Dietz R (2000) Organochlorines in Greenland ringed seals (Phoca hispida). Sci Total Environ 245: 103-116.

27. Vorkamp K, Rigét FF, Glasius M, Muir DCG, Dietz R (2008) Levels and trends of persistent organic pollutants in ringed seals (Phoca hispida) from Central West Greenland, with particular focus on polybrominated diphenyl ethers (PBDEs). Environ Int 34: 499-508.

28. Muir M, Rigét F, Cleemann M, Skaare J, Kleivane L, et al. (2000) Circumpolar trends of PCBs and Organochlorine pesticides in the Arctic Marine Environment inferred from levels in Ringed Seals. Environmental Science and Technology 34: $2431-2438$

29. Rigét $F$, Dietz R, Vorkamp, K, Johansen P, Muir D (2004) Levels and spatial and temporal trends of contaminants in Greenland biota: an updated review. Sci Total Environ 331: 29-52.

30. Beck H, Breuer EM, Droß A, Mathar W (1990) Residues of PCDDs, PCDTs and other organochlorine compounds in harbour seals and harbour porpoise. Chemosphere 20: 1027-1034.

31. Kajiwara N, Rijks JM, Kuiken T, van der Meulen K, Tonegi T, et al. (2008) No sustained decline of PCB and DDT burdens in Dutch harbour seals (Phoca vitulina). In: Rijks J Phocine Distempber revisited. Multidisciplinary analysis of the 2002 phocine distemper virus epidemic in the Nederlands. Proefschrift Erasmus University Rotterdam, The Netherlands, 192.

32. Rigét F, Bignert A, Braune B, Stow J, Wilson S (2010) Temporal trends of legacy POPs in Arctic biota, an update. Science of the Total Environment 408: 2874-84.

33. Boon JP, Van Arnhem E, Jansen S, Kannan N, Petrick G, et al. (1992) The toxicokinetics of PCB in marine mammals with special reference to possible interactions of individual congeners with the Cytochorme P450-dependent monooxygenase system: An overview. In Persistent pollutant in marine ecosystems. Edts: Walker, CH Livingsonte, DR Pergamon Press, Osford, UK, pp. 119-159.

34. Severinsen T, Skaare JU, Lydersen C (2000) Spatial distribution of persistent organochlorines in ringed seal (Phoca hispida) blubber. Marine Environmental Research 49: 291-302.

35. Reijnders PJH (1980) Organochlorine and heavy metal residues in harbou seals from the Wadden Sea and their possible effects on reproduction. Netherlands Journal of Sea Research 14: 30-65

36. Tanabe S, Tatsukawa H, Tanaka K, Maruyama H, Miyazaki M, et al. (1981) Distribution and total burdens of chlorinated hydrocarbons in bodies of striped Dolphins (Stenella coeruleoalba). Agricultural and biological chemistry 45 2569-2578.

37. Debier C, Pomeroy P, Dupont C, Joiris C, Comblin V, et al. (2003) Dynamics of PCB transfer from mother to pup during lactation in UK grey seals Halichoerus grypus: differences in PCB profile between compartments of transfer and changes during the lactation period. Marine Ecology Progress Series 247: 249256 .

38. Heidmann WA, Staats de Yané G, Büthe A, Rüssel-Sinn H (1992) Correlation between concentration and composition of PCB mixtures in seals (Phoca vitulina). Chemosphere 24: 1111-1117.

39. Birnbaum LS (1985) The role of structure in the disposition of halogenated aromatic xenobiotics. Environmental Health Perspective 61: 11-20.

40. Brouwer A, Reijnders PJH, Koeman JH (1989) Polychlorinated biphenyl (PCB) contaminated fish induces vitamin $\mathrm{A}$ and thyroid hormone deficiency in the common seals (Phoca vitulina). Aquatic Toxicology 15: 99-106.

41. Beineke A, Siebert U, MacLachlan M, Bruhn R, Thron K, et al. (2005) Investigations upon the potential influence of environmental contaminants on thymus and spleen of harbor porpoises (Phocoena phocoena). Environmental Science and Technology 39: 3933-3938.

42. Das K, Vossen A, Tolley K, Vikingsson G, Thron K, et al. (2006) Interfollicula fibrosis on the thyroid glands of the harbour porpoise (Phocoena phocoena) An endocrine disruption? Archives of Environmental Contamination and Toxicology 51: 720-729.

43. Das K, Siebert U, Gillet A, Dupont A, Fonfara S, et al. (2008) Mercury in harbour seals (Phoca vitulina) from the North Sea: Full blood concentrations and in vitro Exposure of seal and human peripheral blood mononuclear cells Envrionmental Health 7: 1-17.

44. Kakuschke A, Valentine-Thon E, Griesel S, Fonfara S, Siebert U, et al. (2005) The immunological impact of metals in harbor Seals (Phoca vitulina) of the North Sea. Science of the Total Environment 39: 7568-7575.

45. Ahrens L, Siebert U, Ebinghaus R (2009) Total body burden and tissue distribution of polyfluorinated compounds in harbor seals (Phoca vitulina) from the German Bight. Marine Pollution Bulletin 58: 520-525. 